\title{
Teaching Reform and Innovation of English Listening and Speaking Course Based on New Media Application
}

\author{
Wang Shan ${ }^{1,}$, Weng Liuna ${ }^{1}$ \\ ${ }^{1}$ Huali College Guangdong University of Technology, Guangdong Guangzhou, China \\ ${ }^{a}$ E-mail:31769329@qq.com
}

Keywords: application of new media; comprehensive English; teaching of English listening and speaking course; teaching strategies.

\begin{abstract}
With the emergence of new media, higher education has ushered in new opportunities for development. The present situation of comprehensive English listening and speaking teaching is analyzed, and the ways and means to improve the teaching effect of comprehensive English listening and speaking under the new media environment are explored. The characteristics of new media network learning and its influence are analyzed, and the learning strategies of English listening and speaking courses under the new media network environment are proposed. The analysis of English learning strategies and application can provide reliable guidance for English learners. Comprehensive English listening and speaking teaching has gradually presented the characteristics of modern teaching ideas, and diversified teaching methods and diversified teaching methods, which has injected new vitality into the traditional classroom teaching of comprehensive English listening and speaking. The arrival of the new media age has provided rich and varied curriculum resources for comprehensive English listening and speaking teaching. Based on the MOOC, micro-course and other kinds of online learning platform, students are provided with all kinds of listening and speaking teaching video, the online learning platform is used. In order to strengthen students' autonomous learning ability, teachers should deeply understand and master the relevant technologies of new media, be good at utilizing new media resources, and improve their English teaching level. The theoretical basis, advantages and specific strategies of the application of new media in comprehensive English listening and speaking teaching are analyzed, so as to further improve the teaching level of comprehensive English listening and speaking courses.
\end{abstract}

\section{Introduction}

Comprehensive English is a basic course in the field of higher education in China. It has great significance to improve the comprehensive quality of college students, cultivate their ability of personal development in the future, and improve the level of education and internationalization of talents in our country. However, in the practice of college comprehensive English teaching in China, the application ability of college students' comprehensive English, especially the cultivation of English listening and speaking ability, has always been a "short board" in the field of comprehensive English teaching in China ${ }^{[1]}$. With the deepening of the integration of information 
technology and social production and life represented by the Internet, the information construction of colleges and universities in China has been gradually improved, and the influence of modern educational means and technology on university teaching has become more and more great. Comprehensive English listening and speaking teaching has gradually presented the characteristics of modern teaching ideas, diversified teaching methods and diversified teaching methods, which has injected new vitality into the traditional comprehensive English listening and speaking classroom teaching and achieved great results.

Modern information technology has all affected the social production and life. Under the background of continuing and deepening the reform of higher education in China, comprehensive English education should also actively embrace the modern educational concepts and technologies. Chinese college students' English listening and speaking ability has always been the weakness of college students' English learning. Now, the "Internet" is in full swing in our country, and the development of new media is in the ascendant. Comprehensive English teachers should make full use of the advantages of new media, innovate educational ideas and methods, and promote the integration of new media and comprehensive English listening and speaking teaching ${ }^{[2]}$. With the rapid development of network technology and new media technology, new media tools have attracted the attention of some comprehensive English teachers because of their advantages of openness, pluralism, interactivity and convenience ${ }^{[3]}$. It is also introduced into English listening and speaking classroom teaching to varying degrees. Although the application of new media to comprehensive English listening and speaking teaching is popular among teachers and students, the relevant research is not deep enough, and it is urgent to further strengthen the research work in this field. This paper analyzes the theoretical basis, advantages and specific strategies of the application of new media to comprehensive English listening and speaking teaching, further improves the teaching level of comprehensive English listening and speaking courses, and provides theoretical guidance for the combination of new media and comprehensive English listening and speaking teaching $^{[4]}$.

\section{Theoretical basis of the application of new media in College Comprehensive English listening and speaking teaching}

\subsection{Theory of situational cognition}

The theory of situational cognition is different from the traditional theory of cognition. Its core idea is knowledge, and learning comes from and depends on the situation. Situation is the dynamic development process of interaction between people and people, people and environment. Situational Cognition Theory corrects the previous cognitive theory that knowledge is understood to be based solely on logical rules and information descriptions, which can be obtained through conscious reasoning and thinking ${ }^{[5]}$. Therefore, the concept of cultural background and objective environmental factors on which knowledge is generated is ignored. The application of new media tools is very extensive, its own characteristics can provide conditions, approaches and platforms for situational teaching of comprehensive English, and situational cognitive theory provides theoretical guidance for the application of new media to comprehensive English teaching.

\subsection{Experiential learning theory}

The theory of experiential learning is widely known in the field of education and learning at home and abroad. The theory holds that knowledge is the process of "forming, verifying and reconstructing", which consists of four links with cycle and spiral. The cognitive learning process of experiential learning theory should obtain initial perceptual knowledge (i.e. initial experience) by 
participating in specific practical activities, and then reflect on it through reviewing the perceptual cognition. The inner consciousness and psychological process such as analysis form logical and more abstract experience, and then apply the internalized experience to the practice activity or the realistic situation, and form the re-understanding of the previous experience through comprehension and thinking. The new experiences creatively are reconstructed. Experience is realized by the four-stage cycle, that is, the comprehension and transformation of knowledge ${ }^{[6]}$.

\section{Advantages of using new media in Comprehensive English listening and speaking teaching}

\subsection{Meaning and characteristics of "New Media"}

With the emergence of new media, higher vocational education ushered in new opportunities for development. New media is a relative concept, which is relative to traditional media. Compared with traditional media such as newspapers, radio and television, new media use digital technology, network technology, mobile technology, the Internet, wireless communication network, cable network and other channels. Computers, mobile phones, digital television, touch media QQ, podcast, WeChat, self-media and other carriers are used to provide information to users of the new media form. Digitalization and interactivity are the fundamental features of new media. The new media integrates text, audio and video, breaks the limitation of time, and provides us with a lot of information to meet the individual needs of different people with its various forms of expression ${ }^{[7]}$. In a word, the digitalization, interactivity, uniqueness and initiative of new media have great advantages in English listening and speaking teaching.

\subsection{New media improves the Teaching effect of listening and speaking}

In the new media era, foreign language listening resources are available everywhere. Nowadays, many foreign language learning websites, such as Voice of America, New Oriental, Hujiang, Cocoa listening Web, etc., have platforms and software for listening teaching. They publish all kinds of audio and video programs every day. On VOA, students can freely choose topics of interest under VOA Special English, regular English, lexical allusions, Scientific Americans, and so on according to their English proficiency. Secondly, the phonological function of APP software such as QQ, WeChat YY phonetic software can make English communication between teachers and students and between students and students anytime and anywhere ${ }^{[8]}$. These APP voice-to-speech functions not only reflect the elements of fashion, but also replace the phone-making function of mobile phones to some extent, and can better solve the problem that students and teachers cannot communicate face to face in a timely manner after class. It greatly improves the effectiveness of English listening teaching.

\section{Problems in New Media teaching}

Although the new media teaching has greatly aroused the enthusiasm of the students, made the classroom teaching more vivid and effective, and the teaching quality has been improved to a certain extent, but everything is both pros and cons, so, New media teaching also has its own drawbacks ${ }^{[9]}$.

(1) The teachers lack the ability to operate new media. As a new thing, new media has its unique advantages in comprehensive English classroom, but at the same time, it puts forward higher requirements for teachers to organize and operate classroom. However, some teachers are unfamiliar with this new thing, even if they encounter some simple operational problems in the classroom, they cannot do anything about it, thus wasting the classroom time. In addition, the use of 
new media is presented in the form of teaching courseware to a large extent. Therefore, this requires teachers to understand the process of making new media courseware and related teaching software. However, facts have proved that, many teachers lack the capacity to do so, let alone improve the existing environment for new media use.

(2) The quality of new media teaching courseware is mixed. The making of teaching courseware not only requires the picture and text sound and image, the form is lively, but also should have higher request to its content itself. However, in the actual teaching process, the author found that some courseware only pay attention to the gorgeous appearance, and its content often has one kind of problem. For example, some courseware is tedious and long, with all the details, the emphasis is not prominent, lack of systematization, some teachers copy the contents of the existing courseware, which makes the whole English classroom a simple slide show. For new media students, this form still has some appeal, but over time, students lose their sense of freshness, and even get tired of it. Therefore, the content of the courseware is also more and more demanding.

(3) Some teachers rely too much on new media. New media teaching has greatly enriched the English classroom, made it lively, and effectively improved the quality of teaching. However, some teachers rely too much on new media. In the new media English classroom teaching, the teacher operates the mouse, "demonstrates" the courseware content one by one, unconsciously became the computer operator and the demonstrator. Even the lack of new media cannot teach, so that the teacher's style and personal charm cannot be fully demonstrated. The students also lost their interest in learning English, discouraging their enthusiasm for learning English.

(4) Lack of communication and interaction between teachers and students in new media teaching affects students' initiative. At present, most of the new media courseware is based on constructivism theory. The difference between constructivism theory and traditional educational psychology theory lies in: "it emphasizes that students must change from passive receiver of external stimulus and object of knowledge indoctrination to subject of information processing and active constructor of knowledge meaning". This requires students to give full play to their subjective initiative in their study. However, in the actual teaching process, the computer has to a large extent shared the teaching tasks of the teachers, and the amount of classroom information has increased greatly, and the teachers have become computer operators. The students become passive recipients, lack of communication and interaction between teachers and students, students only mechanically accept knowledge, but cannot process and construct it actively ${ }^{[10]}$.

New media technology has played a great role in promoting the teaching of comprehensive English listening and speaking courses, but it also has some shortcomings. Therefore, we should try our best to find some methods and countermeasures to promote the strengths and circumvent the weaknesses. In order to meet the requirements of the development trend of comprehensive English teaching in our country, the teaching quality of comprehensive English is improved and the teaching of listening and speaking courses is raised to a new stage.

\section{Application of New Media to Comprehensive English listening and speaking teaching}

\subsection{Adopt mixed teaching mode}

The traditional comprehensive English listening and speaking classroom teaching has many shortcomings, but considering all kinds of subjective, external and internal factors, the teacher-led classroom teaching is still the main mode of listening and speaking teaching. Traditional classroom teaching still plays an irreplaceable role in new media teaching. First, many of the basic knowledge and skills in English pronunciation and intonation must be acquired through teachers' on-the-spot teaching and intensive training, which is the advantage of traditional classroom teaching. The majority of college students' English proficiency is not up to the level of fluent conversation, nor is 
it enough to cope with the numerous and complicated languages in the new media. They must lay a solid foundation of language application through classroom listening and speaking and teaching. Finally, college students are learning. In the process of using English listening and speaking ability, there will be many common and universal problems. It is more efficient to solve these problems by unifying and collectivizing classroom teaching. Accordingly, the new media is more suitable for individualized and situational teaching, which is convenient for teachers to give targeted guidance to individual students or a small number of students. Therefore, comprehensive English listening and speaking teaching should make full use of the characteristics and advantages of new media, but the role of traditional classroom teaching should not be ignored ${ }^{[11]}$.

\subsection{Create a second class}

New media is a general term for new electronic media, which is different from traditional print media. Narrow sense of new media mainly refers to specific media products, such as portal, WeChat platform, Weibo and so on, broad new media also includes the Internet, mobile phones and other terminal tools. According to the concept of new media, it covers a lot of content, which provides sufficient conditions for creating the second class of comprehensive English listening and speaking teaching through new media. On the one hand, comprehensive English teachers should actively embrace the changes in the field of education brought about by the Internet and intelligent terminals in a learner's mind, familiarize themselves with the skills and operation of new media, and understand the habits and psychology of college students in using new media. Learning from the excellent English listening and speaking teaching materials on the Internet has the ability to teach English listening and speaking with the help of new media. On the other hand, comprehensive English teachers should focus on the teaching objectives and contents in addition to classroom teaching. Make use of the rich resources on the Internet to select, make close to life, vivid and interesting teaching video, audio and other materials, through the new media recommended to students, guide students in extracurricular learning, training, discussion, teaching, learning, Practice closely combined to create students like the second class.

\subsection{Build a teacher-student interaction system}

Many new media products have not only media properties, but also social attributes. While disseminating information, they can provide users with a platform to express their opinions and communicate with each other. The most typical one is Weixin. Comprehensive English teachers can recommend one-to-many English listening and speaking materials for their students by using the features of Wechat and similar software, as well as individualized guidance one-to-one. Adjustment is the inferiority complex caused by the poor foundation of English, and the reluctance to speak English forms a vicious circle. With the help of new media, students can communicate with their teachers and ask for advice by voice alone, thus avoiding the embarrassment of speaking poor English in public. The interactive system promotes the improvement of classroom teaching effect.

\subsection{English teachers' teaching strategies}

New media network provides a large amount of information for learners and educators. In the face of a large number of good and bad materials, educators should actively and accurately use the cultural background and cultural knowledge of English learning in the new media software. Broaden learners' horizons. In the limited classroom time, teachers should make the best use of the new media to present the focus and difficulty of language knowledge to the learners directly and vividly. At the same time, the study of English as a language should not only pay attention to the 
learning and memory of knowledge points, but also improve the practical application ability of learners. Improving English communicative competence is also one of the keys to English learning. The teaching strategy is to achieve the teaching goal, according to the teaching situation, the teacher makes the overall arrangement to the teaching activity. Teaching strategy is an important part of whether teaching can achieve results. In the bilateral activities between teachers and students, teachers should develop students' metacognitive ability and students' autonomous learning ability.

\section{Conclusions}

The powerful information technology is reshaping the social production and people's way of life. The continuous improvement and extensive use of new media tools have created more possibilities for the innovation of comprehensive English teaching mode. The new media technology has provided the teaching resources and the teaching mode for the college comprehensive English course teaching, especially the listening and speaking course teaching. Students and teachers can obtain the abundant resources in the loose network environment, which is more beneficial to the improvement of the English level. In an interesting and fashionable environment of learning resources, it is very helpful to stimulate students' interest in learning and their ability to express their spoken language. We must deeply understand and master the relevant technologies of new media, and be good at using new media resources. Improve the quality of English teaching.

\section{References}

[1] Feng Lixin. A study on the effectiveness of College English Autonomous Learning Strategies in Network Multimedia Environment [J]. Modern educational technology, 2013, 01: 59-63.

[2] Feng Lixin. A study on the effectiveness of College English Autonomous Learning Strategies in the New Network Media Environment [J]. Modern educational technology, 2013,01:59-63.

[3] Yu Ying. A study on English Learning adaptability in New Media Network assisted Environment [J]. Journal of Beijing University of posts and Telecommunications (Social Sciences Edition),2015, 01:107-113.

[4] Liu Fan, Lu Yuzhu. Strategies for developing critical thinking ability of EFL Autonomous Learners in Network Environment [J]. Audiovisual teaching of foreign languages, 2012, 03:56-61.

[5] Zhang Yuzhen. A study of English Learning Strategies in New Media Network Environment [J]. Chinese Journal (Foreign language Education and Teaching), 2014, 09:92-93,95.

[6] Liu Qizhi, Gan Guosheng. Strategies for College English Vocabulary Learning in the New Media and Network Environment [J]. Modern educational technology 2009, 02:71-73+123.

[7] Zhang Jing. A study on the Application of WeChat in College English listening and speaking Teaching [D]. Northwest normal University, 2015.

[8] Liu Wei. A study on the Optimization of College English listening and speaking Teaching based on Modern Educational Technology [J]. China's audio-visual education, 2013, 10:116-119.

[9] He Haixia. A study on English listening and speaking Teaching Strategies in Western Colleges and Universities under the New Media Environment [J]. Journal of Lanzhou Institute of Education,2015, 11:110-112.

[10] Zhang Yuzhen. Research on English learning strategies under the multimedia network environment [J]. Chinese Language Journal (foreign language education and teaching), 2014, 09:92-93,95.

[11] Hu Jichang. A study on the needs of WeChat in College English listening and speaking Teaching [J]. Curriculum education research,2016, 23:127. 